\title{
Attenuation of antepartum relaxin surge and induction of parturition by antiprogesterone RU 486 in sheep
}

\author{
O. S. Gazal ${ }^{1}, Y . \mathrm{Li}^{1}$, C. Schwabe ${ }^{2}$ and L. L. Anderson ${ }^{1 *}$ \\ ${ }^{1}$ Department of Animal Science, lowa State University, Ames, LA 50011, USA; and ${ }^{2}$ Department of \\ Biochemistry, Medical University of South Carolina, Charleston, SC 29459, USA
}

\begin{abstract}
Pregnant ewes were injected with either the antiprogesterone, $\mathrm{RU} 486\left(4 \mathrm{mg} \mathrm{kg}^{-1}\right.$ body weight, i.m.; $n=5$ ), 3000 iu relaxin (i.m.; $n=9$ ), or diluent $(n=8)$ at $12: 00$ h on days 144 and 145 , to determine its effect on progesterone and relaxin secretion, and on induction of lambing. RU 486 induced earlier lambing $(P<0.01)$ compared with diluent treatment, but relaxin treatment did not significantly reduce the interval to parturition. Mean injectionlambing intervals were $31 \pm 2,109 \pm 23$ and $121 \pm 27 \mathrm{~h}$ for the RU 486, relaxin and diluent groups, respectively. There was no incidence of difficult birth (dystocia); all lambs were vigorous at birth; and placenta delivery was rapid (within $207 \mathrm{~min}$ ) with RU 486 and relaxin treatments compared with diluent treated controls. Plasma progesterone concentrations averaged $11 \mathrm{ng} \mathrm{ml}^{-1}$ during the pretreatment period for all animals. RU $486 \mathrm{had}$ a biphasic effect on progesterone concentrations, causing an initial increase $(P<0.05)$ within $2 \mathrm{~h}$, and then an abrupt drop $(P<0.01)$ to $6 \mathrm{ng} \mathrm{ml}^{-1}$ by 18:00 $\mathrm{h}$ on day 145. Progesterone concentrations remained consistently lower $(P<0.05)$ in relaxin-treated ewes than in diluenttreated controls from days 144 to 147 and then began a steady decrease to $4 \mathrm{ng} \mathrm{ml}^{-1}$ on the day of parturition (days 149 and 150) in both groups. Immunoreactive relaxin concentrations in control ewes increased $(P<0.05)$ from $0.6 \mathrm{ng} \mathrm{m}^{-1}$ to a peak of $3.9 \mathrm{ng} \mathrm{ml}^{-1}$ on day 146 , but they were low $\left(0.8 \mathrm{ng} \mathrm{ml}^{-1}\right)$ at the time of parturition (day 150). RU 486 treatment abruptly increased $(P<0.05)$ circulating relaxin concentration, but the amplitude of this antepartum surge was greatly attenuated compared with that of diluent treated controls. Peak RU 486 concentrations in plasma were 7 and $9 \mathrm{ng} \mathrm{ml}^{-1}$ within $2 \mathrm{~h}$ after first and second i.m. injection of the hormone, respectively, and stabilized at $4 \mathrm{ng} \mathrm{ml}^{-1}$ at the time of induced lambing (day 145). The results reveal that an antepartum relaxin surge occurs in sheep 4 days before normal parturition (day 150), but that RU 486 greatly attenuates the relaxin surge and abruptly decreases circulating progesterone concentration with an induced parturition (day 145). The results indicate that RU 486 can precisely control the time of parturition in sheep in late pregnancy without detrimental effects of dystocia, retention of placenta or delayed postpartum fertility.
\end{abstract}

\section{Introduction}

Relaxin is a peptide hormone produced in greatest concentrations by female reproductive tissues, particularly during pregnancy (Anderson, 1987; Sherwood, 1988). Maximum peripheral blood concentrations of relaxin occur a few hours before parturition in rats and pigs, but no similar evidence is available for sheep (Sherwood ef al., 1980; Felder et al., 1986). Low relaxin immunoreactivity has been reported in placental, endometrial and ovarian tissues $\left(0.05-11.00 \mathrm{ng} \mathrm{g}^{-1}\right)$ of ewes from day 21 to parturition, but no obvious trend was found throughout pregnancy (Renegar and Larkin, 1985; Wathes et al., 1988). Relaxin increases cervical compliance in oestrogen-primed ovariectomized ewes (Nemec et al., 1988) and reduces uterine

*Reprint requests.

Received 2 March 1992 contractility (Porter et al., 1981), thus suggesting a role for this hormone in pregnancy.

Maintenance of pregnancy in mammals, including sheep, requires the binding of progesterone to its receptor in the uterine endometrium leading to the proliferation of the epithelial and vascular cells. A decrease in circulating progesterone concentrations must precede induced or spontaneous parturition in ewes (Stabenfeldt et al., 1972; Ledger et al., 1985), and this can be achieved by blocking progesterone synthesis with $3 \beta$ hydroxysteroid dehydrogenase inhibitors (Taylor, 1987). RU 486 (11 $\beta$-[4-dimethyl-amino phenyl]17 $\beta$-hydroxy-17 $\alpha$-[1-propynyl] estra-4,9-dien-3-one) is a 19-norsteroid with potent antiprogesterone and antiglucocorticoid activities (Baulieu, 1989), and it reduces maternal progesterone concentrations in several species including pigs, cattle, monkeys (Rhesus and Macaca fascicularis), and humans (Nieman et al., 1987; Baulieu, 1989; Puri et al., 1990; Li et al., 1991a, b). RU 486 binds competitively to progesterone 
receptors and such binding either blocks the interaction between progesterone receptors and DNA or impairs gene transactivation. Substitution of glycine by cysteine at position 575 in the human progesterone receptor abrogates binding of RU 486, but not that of an agonist (Benhamou et al., 1992). Relaxin administered to cattle late in pregnancy decreases circulating progesterone and also advances parturition (Musah et al., 1986; Bagna et al., 1991) and it decreases progesterone in cyclic ewes (Akinbami et al., 1990). RU 486 can modulate both progesterone and relaxin secretion in pigs, but responses depend on the presence or absence of the uterus (Li et al., 1991b). In pregnant pigs, RU 486 advanced the time and increased the amplitude of peak relaxin release and abruptly decreased circulating progesterone concentrations, whereas in hysterectomized animals the same RU 486 treatment delayed the time of peak relaxin release and abruptly increased progesterone secretion.

Our studies in pigs and cattle indicate that RU 486 is a useful probe for determining the physiological roles of progesterone during pregnancy. The mechanism by which progesterone and relaxin secretion are regulated during late pregnancy in sheep is undefined. It is hypothesized that RU 486 could decrease progesterone secretion in pregnant sheep, but it is not known whether the drug can alter endogenous relaxin secretion. Whether exogenous relaxin could alter progesterone secretion in this species is undefined. This study was designed to determine the effects of both RU 486 and relaxin on antepartum progesterone and relaxin secretion in late pregnant sheep. Furthermore, the effects of RU 486 and relaxin on the time and ease of parturition as well as viability of lambs were determined.

\section{Materials and Methods}

\section{Animals}

Twenty-two ewes of Suffolk and Hampshire breeds, averaging $97 \pm 2 \mathrm{~kg}$ body weight (mean \pm SEM) were maintained at the Sheep Teaching Farm, lowa State University. Animals received $1.8 \mathrm{~kg}$ of chopped hay and $0.5 \mathrm{~kg}$ of corn daily. Water was provided ad libitum. Ewes were naturally mated at oestrus $($ day $=0)$. The average duration of gestation in this flock is 150 days.

\section{Experimental groups}

The ewes were randomly allocated to one of three treatments: RU 486 group $(n=5)$; relaxin group $(n=9)$; and diluent group $(n=8)$. On day 140 of gestation, one external jugular vein of each ewe was fitted with an indwelling catheter (i.d. $0.127 \mathrm{~cm}$; o.d. $0.299 \mathrm{~cm}$; Tygon Microbore tubing, No. 14170-15E, Fisher Scientific Co., Pittsburgh, PA) for repeated blood sampling. On days $140-143$, a blood sample was collected once a day at 12:00 h. On day 144 , beginning at $11: 00 \mathrm{~h}$, blood samples were obtained at intervals of $15 \mathrm{~min}$ for $1 \mathrm{~h}$; and at $12: 00 \mathrm{~h}$, ewes in the RU 486, relaxin, or diluent groups received i.m. injection of either RU $486\left(4 \mathrm{mg} \mathrm{kg}^{-1}\right.$ body weight in $3 \mathrm{ml}$ of ethanol), relaxin (CM-B fraction, $3000 \mathrm{iu} \mathrm{mg}^{-1}$ with $1 \mathrm{mg}$ relaxin in $3 \mathrm{ml}$ of phosphate-buffered saline, PBS), or diluents (PBS and ethanol) in separate sites, respectively.
Relaxin for this experiment was extracted from the ovaries of pregnant pigs and purified according to procedures described previously (Büllesbach and Schwabe, 1985). Sequential blood samples were collected at intervals of $15 \mathrm{~min}$ for $1 \mathrm{~h}$ after treatment and 2,3,9 and $15 \mathrm{~h}$ later. Ewes not lambing by 11 :00 $\mathrm{h}$ on day 145 received a second injection of RU 486 or relaxin and were bled using the same regimen as described for day 144 . From day 146 to 2 days post partum, blood samples were collected once a day at 12:00 h. The catheter was flushed with heparinized saline (100 iu ml ${ }^{-1}$ ) after each blood collection. Blood samples $(10 \mathrm{ml})$ were collected in $16 \times 100 \mathrm{~mm}$ borosilicate culture tubes maintained on ice. Tubes were centrifuged at $2000 \mathrm{~g}$ for $10 \mathrm{~min}$ and the plasma was immediately harvested into $12 \times 75 \mathrm{~mm}$ culture tubes, frozen on dry ice and stored at $-20^{\circ} \mathrm{C}$ until required for radioimmunoassay of progesterone, relaxin and RU 486.

Ewes exhibiting signs of imminent lambing were kept in the maternity barn for continuous observation. Duration of gestation, exact time of lambing, time of placental delivery and sex and body weights of lambs were recorded at lambing. The interval from first hormone or diluent injection to parturition was calculated to determine the injection-lambing interval.

\section{Radioimmunoassays of $R U 486$, relaxin and progesterone in peripheral plasma}

RU 486 concentrations in the plasma were determined by radioimmunoassay procedures as previously described (Salmon and Mouren, 1985; Heikinheimo et al., 1986) with modifications (Li et al., 1991a, b, c). The specific activity of $\left[{ }^{3} \mathrm{H}\right] \mathrm{RU} 486$ was $46.8 \mathrm{Ci} \mathrm{mmol}^{-1}$ (433.59 molecular weight). The anti-RU 4863-carboxylmethyloxime-BSA antiserum was raised in New Zealand White rabbits according to procedures described previously (Raynaud et al., 1974). Plasma samples $(50 \mu \mathrm{l})$ in duplicate were added to $0.25 \mathrm{ml}$ distilled water and extracted with $3.0 \mathrm{ml}$ diethyl ether (spectrophotometric grade; Aldrich, Milwaukee, WI). The recovery of radioactivity was $79.3 \%(n=$ 2). Total incubation volume was $0.4 \mathrm{ml}$ tube $^{-1}$ in which antiserum was diluted to $1: 10000$ and total $\left[{ }^{3} \mathrm{H}\right] \mathrm{RU} 486$ was 10000 c.p.m. The standard curve contained $0,20,40,80,125$, 250,1000 and $2000 \mathrm{pg}$ tube ${ }^{-1} \mathrm{RU} 486$ in duplicate. Separation of unbound fraction was obtained by dextran-coated charcoal. Sensitivity of the assay was $10 \mathrm{pg}$ tube ${ }^{-1}$, and the intra- and interassay coefficients of variation were $8.0 \%(n=2)$ and $18 \%$ $(n=2)$, respectively; non-specific binding was $9.0 \%$.

A homologous double antibody radioimmunoassay for porcine relaxin was used as described by $\mathrm{O}^{\prime}$ Byrne and Steinetz (1976) with modifications to quantify relaxin concentration in ovine plasma in duplicate aliquots of $50-200 \mu \mathrm{l}$. The assay buffer was $0.01 \mathrm{~mol}$ phosphate-buffered saline (PBS)-1\% bovine serum albumin (BSA). Monotyrosylated porcine relaxin (Schwabe, 1983) was iodinated with $\mathrm{I} \mathrm{mCi}{ }^{125} \mathrm{I}$ (IMS 30; Amersham Corp, Arlington Heights, IL) according to the chloramine T procedure. $100 \mu \mathrm{l}$ of $\left.{ }^{125} \mathrm{I}\right]$-porcine monotyrosyl relaxin (10 000 c.p.m. in $0.01 \mathrm{~mol} \mathrm{PBS}^{-1}-1 \% \mathrm{BSA}$ ) was added to all tubes. Antiporcine relaxin antibody (Dual Rabbit R6) was added at a 1:10000 dilution in $0.05 \mathrm{~mol}$ ethylenediaminetetraacetic acid $\mathrm{l}^{-1}$-PBS and $6 \%$ normal rabbit serum to all tubes except the nonspecific binding and total count tube, which received buffer only. The 
Table 1. Effect of antiprogesterone RU 486 and relaxin on pregnancy and parturition in sheep

\begin{tabular}{|c|c|c|c|c|c|c|c|c|c|}
\hline & \multirow{2}{*}{\multicolumn{2}{|c|}{ Ewe }} & \multirow{3}{*}{$\begin{array}{l}\text { Pregnancy } \\
\text { duration } \\
\text { (days) }\end{array}$} & \multirow{3}{*}{$\begin{array}{c}\text { First } \\
\text { treatment to } \\
\text { first lambing } \\
\text { (h) }\end{array}$} & \multirow{3}{*}{$\begin{array}{c}\text { Time from } \\
\text { lambing to } \\
\text { placental delivery } \\
\text { (min) }\end{array}$} & \multicolumn{4}{|c|}{ Lamb } \\
\hline & & & & & & \multirow{2}{*}{$\begin{array}{c}\text { Birth } \\
\text { weight } \\
(\mathrm{kg})\end{array}$} & \multirow[b]{2}{*}{$\begin{array}{l}\text { Number } \\
\text { per ewe }\end{array}$} & \multicolumn{2}{|c|}{ Sex } \\
\hline & $(n)$ & $\begin{array}{l}\text { Body } \\
\text { weight } \\
(\mathrm{kg})\end{array}$ & & & & & & $\begin{array}{c}\text { Male } \\
(n)\end{array}$ & $\begin{array}{c}\text { Female } \\
(n)\end{array}$ \\
\hline RU 486 & 5 & $94 \pm 6$ & $145 \pm 0.2^{*}$ & $31 \pm 2^{* *}$ & $204 \pm 17$ & $5.1 \pm 0.4$ & 1.8 & 6 & 3 \\
\hline Relaxin & 9 & $100 \pm 5$ & $149 \pm 0.7$ & $109 \pm 23$ & $183 \pm 21$ & $4.1 \pm 0.2$ & 2.3 & 8 & 13 \\
\hline Diluent & 8 & $96 \pm 4$ & $150 \pm 0.8$ & $121 \pm 27$ & $193 \pm 17$ & $4.3 \pm 0.2$ & 2.0 & 9 & 7 \\
\hline
\end{tabular}

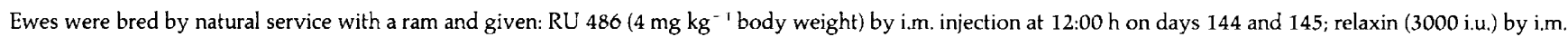
injection at these same times on days 144 and 145; and diluent by i.m. injection on days 144 and 145 .

Values are means \pm SEM. ${ }^{*} P<0.05$ and ${ }^{* *} P<0.01$ compared with diluent-treated controls.

tubes were incubated for $24 \mathrm{~h}$ at $4{ }^{\circ} \mathrm{C}$, and $200 \mu \mathrm{l}$ of 1:10 goat rabbit $\gamma$ globulin antiserum (No. 0112-0081 Lot No. 33091; Organon Teknika Co., PA) was added to all tubes except total count tubes, which received the buffer $\left(0.01 \mathrm{~mol} \mathrm{PBS}^{-1}\right)$. After incubating for $18-24 \mathrm{~h}, 3 \mathrm{ml}$ of $0.01 \mathrm{~mol} \mathrm{PBS} \mathrm{l}^{-1}-1 \%$ BSA was added to all tubes except total count tubes and centrifuged at $2000 \mathrm{~g}$ for $30 \mathrm{~min}$. The pellets were counted for $2 \mathrm{~min}$ in an automatic gamma counter (Packard Cobra Auto Gamma 5003). Accuracy and precision of the assay were determined by adding known amounts of standard porcine relaxin (purified pig CM-B relaxin, $3000 \mathrm{iu} \mathrm{mg}^{-1}$, to plasma $(200 \mu \mathrm{l})$ from ovariectomized hysterectomized sheep, as follows: $0.10,0.25,0.50,1.00,2.00$, $3.00,4.00$ and $5.00 \mathrm{ng} \mathrm{ml}^{-1}$ in quadruplicate aliquots. The plasma blank values were assayed and the values subtracted from those tubes containing known amounts of relaxin. Concentrations $\left(\mathrm{ng} \mathrm{m}^{-1}\right)$ of relaxin averaged $0.12 \pm 0.020,0.24 \pm$ $0.030,0.48 \pm 0.010,1.1 \pm 0.03,1.9 \pm 0.06,2.3 \pm 0.07,4.1 \pm$ 0.13 and $5.2 \pm 0.06$, respectively. A pool of sheep blood plasma with high relaxin immunoreactivity was assayed in quadruplicate at volumes of 50, 100, 200 and $400 \mu \mathrm{l}$ and showed parallelism in a dose-dependent manner with porcine relaxin added to plasma from ovariectomized ewes. Intra- and interassay coefficients of variation were $5.6 \%(n=3)$ and $9.7 \%(n=3)$, respectively. The nonspecific binding of the assay was $2.08 \%(n=3)$, and the maximum binding of the first antibody was $33 \%$.

Progesterone was determined in $200 \mu$ l aliquots of plasma, as described by Musah et al. (1986), using the progesterone antibody GDN-337 (Niswender, 1973). Plasma was extracted with a benzene:hexane mixture $(1: 2, v / v)$. Precision and accuracy were validated by adding known quantities of standard progesterone, $0.00,0.50,1.25,2.50,3.75,5.00,7.50,12.50$ and $25.00 \mathrm{ng}$ to $200 \mu \mathrm{l}$ of ovariectomized sheep plasma in quadruplicate aliquots. These standard samples were assayed and the concentrations of progesterone (mean \pm SEM) were 0.00 , $0.50 \pm 0.002,1.31 \pm 0.020,2.6 \pm 0.03,3.0 \pm 0.09,4.5 \pm$ $0.33,6.0 \pm 0.24,11.7 \pm 0.33$ and $24.8 \pm 0.95 \mathrm{ng}$, respectively. The sensitivity of the assay was $0.25 \mathrm{ng} \mathrm{ml}^{-1}$. The nonspecific binding of all assays was $3.0 \%(n=4)$ and the maximum antibody binding was $34.3 \%(n=4)$. The overall extraction efficiency was $84.8 \%(n=4)$ and the intra- and interassay coefficients of variation were $4.8 \%(n=4)$ and $8.1 \%$ $(n=4)$, respectively.

\section{Statistical analyses}

Results are expressed as means \pm SEM. The experimental units in this study were the individual animals randomly assigned to treatments. Data were analysed by split-plot design using both the general linear model and Student's $t$ test for comparisons between treatment groups (Blair et al., 1979; Snedecor and Cochran, 1989).

\section{Results}

\section{Effects of RU 486 and relaxin on induction of parturition and survival of lambs}

Intramuscular injections of RU 486 to late pregnant ewes induced a markedly earlier lambing than did diluent treatment (Table 1). RU 486 ewes lambed $31 \mathrm{~h}$ after the first RU 486 injection, but the injection-lambing interval was variable and not statistically different between relaxin-treated $(109 \mathrm{~h})$ and diluent-treated ( $121 \mathrm{~h}$ ) ewes. The time interval between the first lamb and the expulsion of the last placenta was similar among the three groups, averaging 207, 183 and $193 \mathrm{~min}$ in the RU 486, relaxin and diluent groups, respectively. Birth weights were similar among groups. At birth, all single-, twin-, and tripletborn lambs could breathe, walk and suck. Hence, the survival and vigour of the lambs were unaffected by RU 486 or relaxin treatment. The ewes were successfully bred in the next breeding cycle.

\section{Effects of RU 486 and relaxin on maternal peripheral progesterone concentration}

The progesterone concentration averaged $11 \pm 0.6 \mathrm{ng} \mathrm{ml}^{-1}$ during the pretreatment period. During the post-treatment period, overall plasma progesterone concentrations were significantly lower in RU 486- $\left(8 \pm 0.7 \mathrm{ng} \mathrm{ml}^{-1} ; P<0.05\right)$ and relaxin- $\left(8 \pm 0.4 \mathrm{ng} \mathrm{ml}^{-1} ; P<0.05\right)$ groups compared with diluent-treated controls ( $11 \pm 0.6 \mathrm{ng} \mathrm{m}^{-1}$; Fig. 1) as determined by general linear model analysis. RU 486 had a biphasic effect on blood progesterone concentrations with an initial 


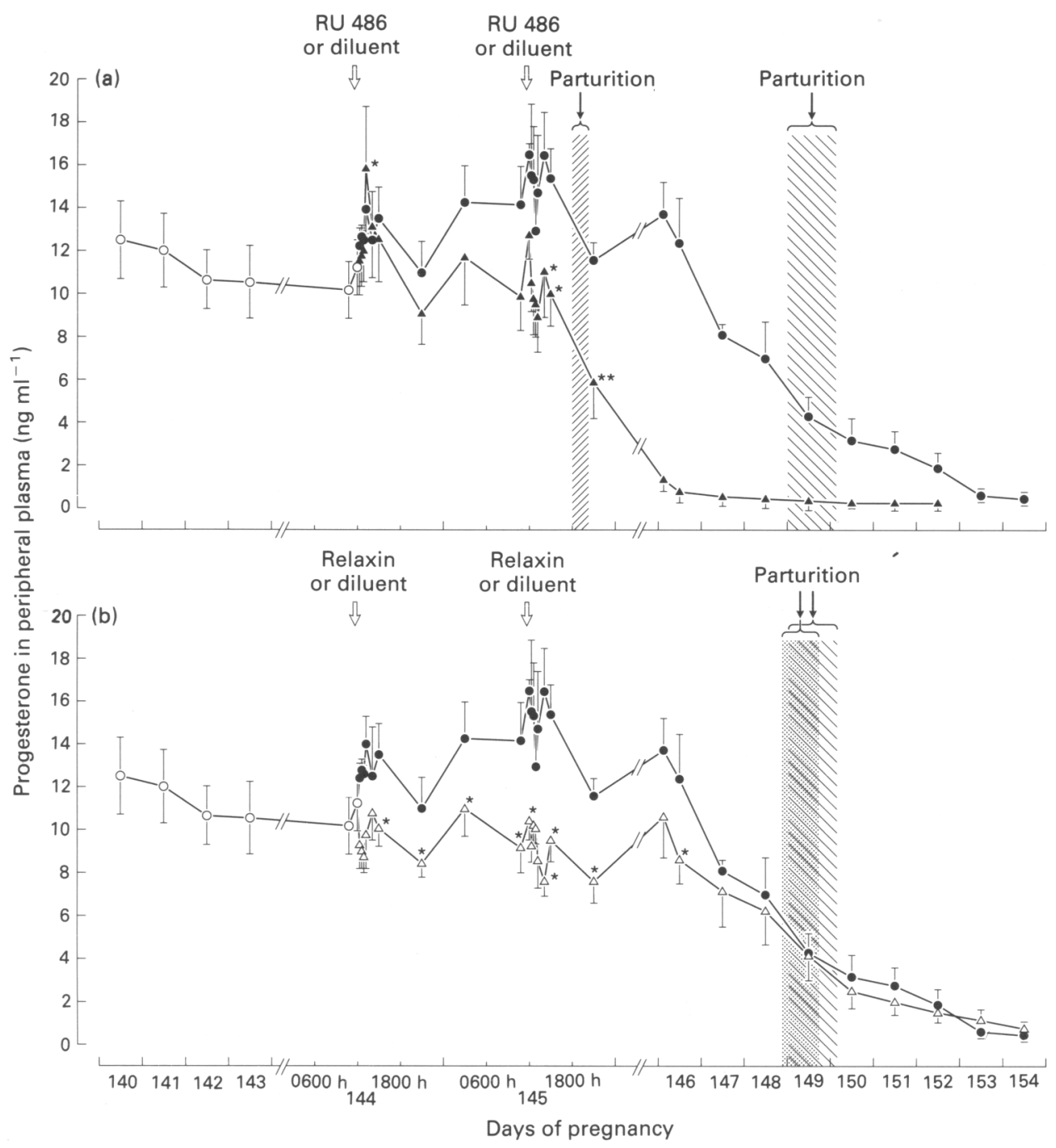

Fig. 1. Effect of (a) the antiprogesterone RU 486 and (b) relaxin on progesterone concentrations in peripheral plasma during late pregnancy in sheep. On day 140 , an indwelling catheter was inserted into a jugular vein for repeated blood sample collection from days 140-143 and day of lambing to 2 days post partum. Blood was collected once a day at $12: 00 \mathrm{~h}$; on days 144 and 145 at 12:00 $\mathrm{h}$, the ewes were injected with (a) RU 486 ( $4 \mathrm{mg} \mathrm{kg} \mathrm{kg}^{-1}$ body weight, i.m.), and (b) relaxin (3000 iu, i.m.). The controls received i.m. injections of $3 \mathrm{ml}$ diluent. Blood was collected at $-60,-45,-30,-15 \mathrm{~min}$ before treatment and immediately after treatment at 15, 30, 45, $60 \mathrm{~min}$ and at 2,3,9, and $15 \mathrm{~h}$. Progesterone concentrations $\left(\mathrm{ng} \mathrm{ml}^{-1}\right)$ are indicated during the pretreatment period $(\mathrm{O}, n=22)$; after the RU 486 treatment $(\boldsymbol{\Delta}, n=5)$, after the relaxin treatment $(\triangle, n=9)$, and after the diluent treatment $(\boldsymbol{O}, n=8)$. Times of hormone and diluent treatments are indicated by open arrows. The solid arrows indicate the mean and the bars indicate the standard error for the time of parturition in the RU 486-treated ewes ( $\mathbb{Z}$ ), relaxin-treated ewes (图), and diluent-treated controls $(\mathbb{S})$. Results are expressed as means \pm SEM. ${ }^{*} P<0.05$ and ${ }^{* *} P<0.01$ compared with diluent-treated controls.

marked increase $(P<0.05)$ within $2 \mathrm{~h}$ compared with the pretreatment period, and a consistent decrease $(P<0.05)$ by $9 \mathrm{~h}$ compared with diluent-injected controls (Fig. 1a). Progesterone averaged $6 \mathrm{ng} \mathrm{ml}^{-1}$ in the RU 486 treated ewes at induced lambing on day 145 compared with $11 \mathrm{ng} \mathrm{ml}^{-1}$ in the controls $(P<0.01)$ at that time. Up to day 147 , progesterone was consistently lower $(P<0.05)$ in the relaxin-injected ewes than in the controls and then it decreased steadily until parturition occurred on days 149 and 150 in both groups (Fig. 1b). At parturition, progesterone averaged $4 \mathrm{ng} \mathrm{ml}^{-1}$ in relaxin- and diluent-treated ewes (Fig. Ib).

\section{Immunoreactive relaxin plasma concentrations}

In the control ewes, immunoreactive relaxin concentrations increased $(P<0.05)$ with advancing gestation, reaching a peak of $3.9 \mathrm{ng} \mathrm{ml}^{-1}$ on day 146 (Fig. 2). On the day of parturition (day 150), relaxin concentrations were low, averaging 


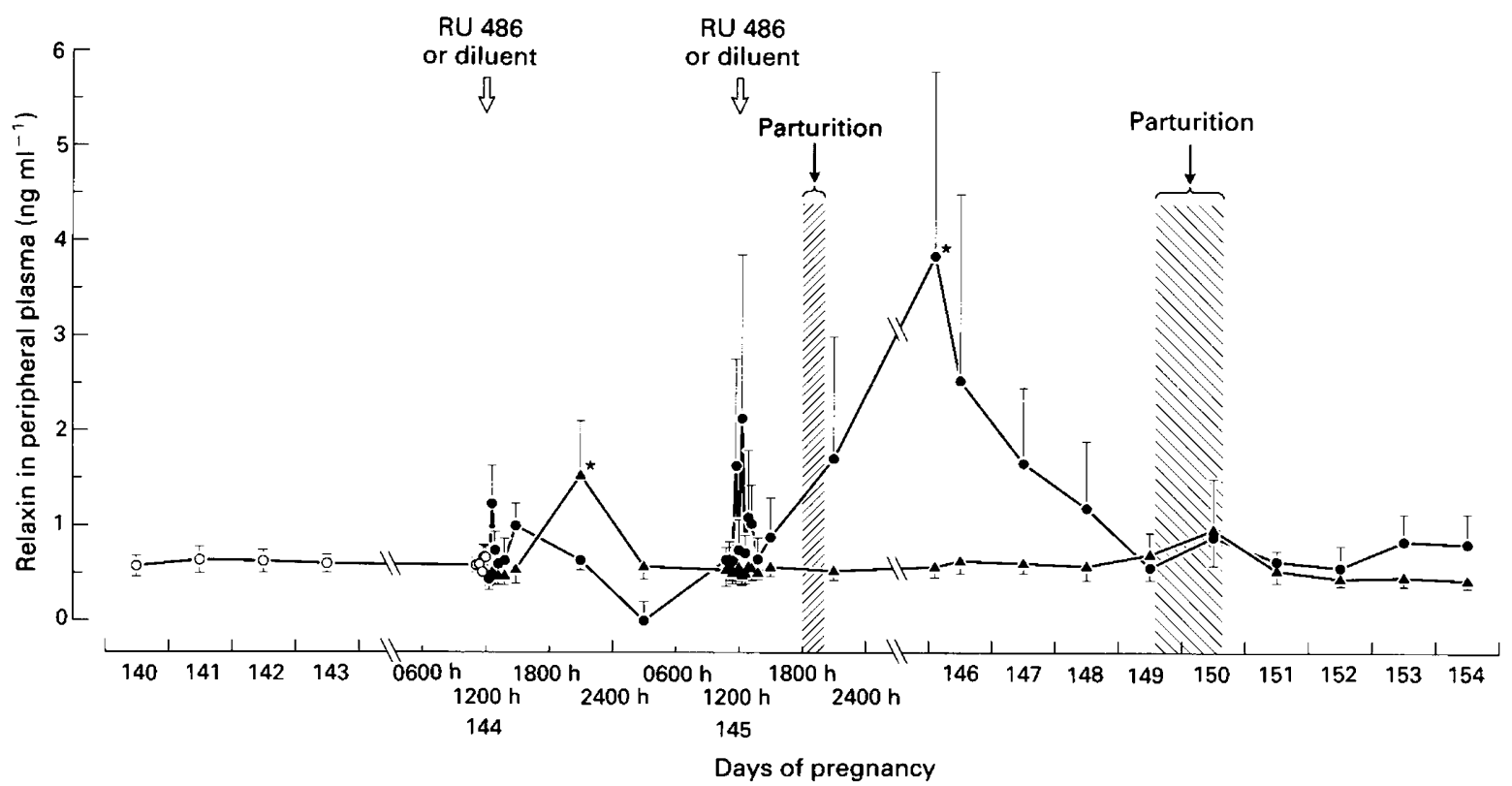

Fig. 2. Effect of RU 486 on relaxin concentrations in peripheral plasma during late pregnancy in sheep. On day 140 , an indwelling catheter was inserted into a jugular vein for repeated blood sample collection from days 140-143 and day of lambing to 2 days post partum. Blood was collected once a day at $12: 00 \mathrm{~h}$; on days 144 and 145 at $12: 00 \mathrm{~h}$, ewes were injected with RU 486 (4 mg kg ${ }^{-1}$ body weight, i.m.). The controls received i.m. injections of $3 \mathrm{ml}$ diluent. Blood was collected at $-60,-45,-30,-15 \mathrm{~min}$ before treatment and immediately after treatment at 15,30,45,60 min and at 2, 3, 9, and $15 \mathrm{~h}$. Relaxin concentrations (ng $\mathrm{ml}^{-1}$ ) are indicated during the pretreatment period $(O, n=22)$; after the $\operatorname{RU} 486$ treatment $(\boldsymbol{\Delta}, n=5)$ and after the diluent treatment $(\odot, n=8)$. Times of RU 486 and diluent treatments are indicated by open arrows. The solid arrows indicate the mean and the bars

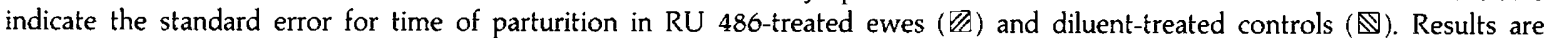
expressed as means \pm SEM. ${ }^{*} P<0.05$ compared with diluent treated control ewes.

$0.8 \mathrm{ng} \mathrm{ml}^{-1}$. RU 486 caused a small but significant increase $(P<0.05)$ in circulating relaxin within $8 \mathrm{~h}$ after treatment, but relaxin remained at basal concentrations at the time of induced parturition (Fig. 2). Relaxin concentrations remained consistently less $(P<0.01)$ in the RU 486-treated group $\left(0.5 \mathrm{ng} \mathrm{ml}^{-1}\right)$ than in the controls $\left(1.5 \mathrm{ng} \mathrm{ml}^{-1}\right)$ from 5 days before and up to the day of parturition. During the overall post-treatment period, immunoreactive relaxin was lower $(P<0.05)$ after RU $486\left(0.6 \pm 0.03 \mathrm{ng} \mathrm{ml}^{-1}\right)$ than after diluent treatment (1.2 $\left.\pm 0.17 \mathrm{ng} \mathrm{ml}^{-1}\right)$.

Relaxin i.m. injection abruptly increased $(P<0.01)$ the circulating relaxin concentration from 0.6 to $45 \mathrm{ng} \mathrm{ml}^{-1}$ on day 144 (Fig. 3b). Relaxin increased $(P<0.01)$ within $15 \mathrm{~min}$, peaked within $1 \mathrm{~h}$, and basal concentrations were reached $24 \mathrm{~h}$ later. The second i.m. injection of relaxin, given $24 \mathrm{~h}$ after the first, increased circulating relaxin within $15 \mathrm{~min}$ and reached a peak of $49 \mathrm{ng} \mathrm{ml}^{-1}$ within $2 \mathrm{~h}$; basal values were reached $48 \mathrm{~h}$ after the second hormone injection. During the post-treatment period, relaxin averaged $20 \pm 1.7 \mathrm{ng} \mathrm{ml}^{-1}(P<0.01)$ in the relaxin-treated ewes compared with $1.2 \pm 0.17 \mathrm{ng} \mathrm{ml}^{-1}$ in diluent-treated controls. As observed in both the RU 486- and diluent-treated controls circulating relaxin was also low on the day of parturition in this group.

\section{RU 486 concentrations in peripheral plasma}

Intramuscular injection of RU 486 abruptly increased $(P<0.001)$ circulating RU 486 within 15 min, reaching a peak value of $7 \mathrm{ng} \mathrm{ml}^{-1}$ within $2 \mathrm{~h}$ (Fig. 3a). During the next $24 \mathrm{~h}$, RU 486 concentrations were maintained at $4 \mathrm{ng} \mathrm{m}^{-1}$ and the second injection of the drug, $24 \mathrm{~h}$ after the first, caused a further increase $(P<0.001)$ to $8.0 \mathrm{ng} \mathrm{ml}^{-1}$ within $15 \mathrm{~min}$ and a peak of $9 \mathrm{ng} \mathrm{ml}^{-1}$ by $45 \mathrm{~min}$. RU 486 averaged $5 \pm 0.7 \mathrm{ng} \mathrm{ml}^{-1}$ at the time of induced parturition.

\section{Discussion}

The results indicate that RU 486 can precisely control parturition in sheep in late pregnancy. RU 486 had a biphasic effect on concentrations of progesterone in peripheral blood, with an initial increase $1 \mathrm{~h}$ in duration that was followed by a marked and consistent decrease $9 \mathrm{~h}$ after RU 486 injection. A similar biphasic response has been observed in cultured human syncytiotrophoblasts incubated with RU 486 (Das and Catt, 1987). The initial increase in circulating progesterone concentration in sheep may result from the disinhibition of pituitary luteinizing hormone (LH) secretion arising from RU 486 blockage of progesterone receptor. RU 486 can induce changes in the frequency of LH pulsatility (Garzo et al., 1988; Swahn et al., 1990). RU 486 administration to women during the follicular, early luteal and midluteal phases of the menstrual cycle increases $\mathrm{LH}$ secretion leading to increased circulating progesterone concentrations (Herrmann et al., 1985; Shoupe et al., 1987; Garzo et al., 1988). In hysterectomized pigs, RU 486 caused a dosedependent increase in progesterone concentration that lasted 

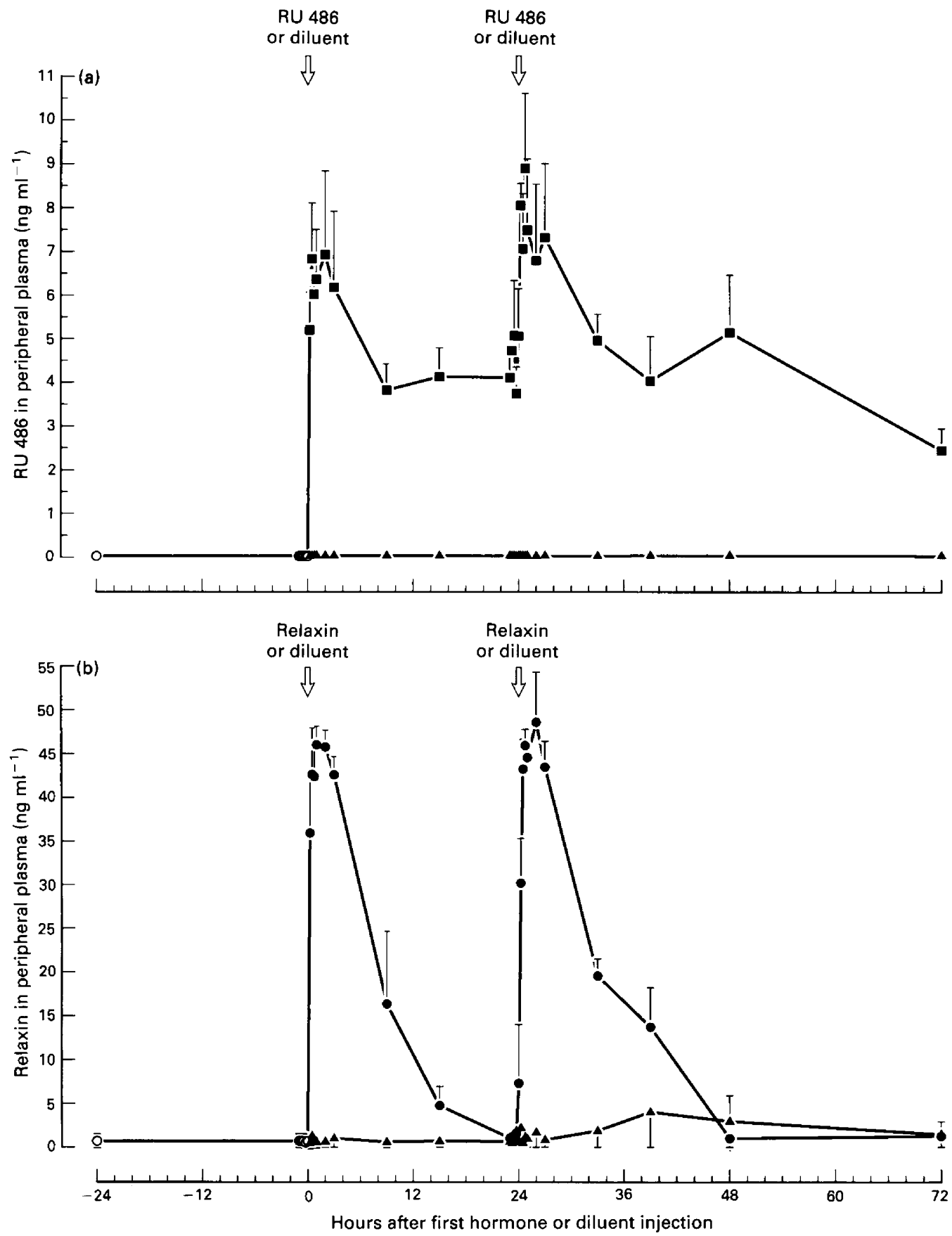

Fig. 3. Comparison of (a) RU 486 and (b) relaxin in peripheral plasma during late pregnancy in sheep. On day 140, an indwelling catheter was inserted into a jugular vein for repeated blood sample collection from days 140143 and day of lambing to 2 days post partum. Blood was collected once a day at 12:00 h; on days 144 and 145 at 12:00 h, the ewes were injected with (a) RU 486 ( $4 \mathrm{mg} \mathrm{kg}^{-1}$ body weight, i.m.), and (b) relaxin (3000 iu, i.m.). The controls received i.m. injections of $3 \mathrm{ml}$ diluent. Blood was collected at $-60,-45,-30,-15$ min before treatment and immediately after treatment at 15,30,45,60 min and at 2,3, 9, and $15 \mathrm{~h} .(\mathrm{O})$, pretreatment $(n=22)$; $(\boldsymbol{\square})$, treatment with RU $486\left(4 \mathrm{mg} \mathrm{kg}^{-1}\right.$ body weight; i.m., $\left.n=5\right)$; $(\Theta)$, treatment with $3000 \mathrm{U}$ relaxin (i.m., $n=9$ ); $(\boldsymbol{\Delta})$, diluent-treated controls $(n=8)$. Values are means \pm SEM. Times of hormone and of diluent treatments are indicated by open arrows.

throughout the 5-day treatment (Li et al., 1991b). Furthermore, intracerebroventricular infusion of RU 486 increased prolactin plasma concentration within $20 \mathrm{~min}$ in hysterectomized pigs ( $\mathrm{Li}$ et al., 1992), and it is known that prolactin is required for progesterone and relaxin secretion by ageing corpora lutea in this species (Li et al., 1989). In sheep, placental progesterone synthesis accounts for up to $80 \%$ of circulating progesterone in the last two-thirds of pregnancy. How RU 486 compromises 
placental steroidogenesis is undefined. In both monkeys (Macaca fascicularis) and humans, transplacental transfer of RU 486 occurs from the maternal blood to the fetal circulation (Wolf et al., 1988; Hill et al., 1990). RU 486 inhibited placental protein synthesis within $6 \mathrm{~h}$ of in vitro incubation (Ogle, 1988), and decreased human chorionic gonadotrophin (hCG) production by explants of human trophoblast (Swahn et al., 1990), as well as production of progesterone, hCG and oestrogen by dispersed human syncytiotrophoblast (Bischof et al., 1986). Thus, RU 486 may act acutely within the central nervous system via gonadotrophin-releasing hormone to increase progesterone secretion and then act chronically, possibly at the level of the trophoblast, to decrease progesterone secretion through enzymatic pathways.

The induced parturition by RU 486 may result primarily from abrupt progesterone withdrawal. RU 486 blocks the progesterone receptor at the level of the trophoblast and downregulates nuclear progesterone receptors in decidualized cells ( $\mathrm{Vij}$ et al., 1989). The withdrawal of progesterone would permit uterine contractions by stimulating oestrogen receptor synthesis or enhancing endometrial prostaglandin synthesis (Kelly et al., 1984, 1986; Haluska et al., 1990). The decrease in circulating progesterone with a coincident increase in oestrogen may stimulate gap junction formation. In late pregnant rats, RU 486 stimulates extensive development of gap junctions, which is soon followed by birth of pups (Garfield et al., 1987). Gap junctions permit coordinated myometrial contractility and convert the uterus into a functional syncytium responding to the stimulatory actions of prostaglandins and oxytocin. RU 486 markedly decreased circulating progesterone concentrations within $24 \mathrm{~h}$ in late pregnant cows and pigs ( $\mathrm{Li}$ et al., 1991a, b), which was similar to that seen in late pregnant sheep in this study. The abortifacient actions of RU 486 may result from an interplay of prostaglandins, glucocorticoids, and oxytocin on the maternal uterus and cervix for expulsion of the conceptus(es). Acting also as an antiglucocorticoid compound, RU 486 disrupts the negative feedback loop of the hypothalamuspituitary-adrenal axis and causes increased blood concentrations of cortisol and adrenocorticotrophic hormone in pregnant laboratory animals and in women (Gaillard et al., 1984; Healy et al., 1985; Heikinheimo et al., 1990). The extent to which the antiglucocorticoid activity of RU 486 contributed to its parturition inducing ability in this study with sheep was not determined. RU 486 may also block the glucocorticoid negative feedback at the fetal pituitary gland and therefore induce compensatory increases in plasma adrenocorticotrophic hormone and in cortisol.

This is the first report of an antepartum relaxin surge in late pregnant sheep, as has been found in rats and pigs (Sherwood, et al., 1980; Felder et al., 1986). In these ewes, immunoreactive relaxin in the circulating blood peaked 4 days before normal parturition at day 150 , but the modest amplitude of this relaxin surge differs greatly from that seen in pigs and rats. The significance of this antepartum relaxin release is not clear; however, it occurred earlier in sheep than in rats and pigs. RU 486 treatment in late pregnant pigs caused a greater peak relaxin release that occurred significantly earlier than that seen in placebotreated controls ( $\mathrm{Li}$ et al., 1991b). Relaxin concentration in peripheral plasma of both RU 486- and placebo-treated pigs was low at the time of induced or normal parturition. The antepartum increase in circulating relaxin concentrations in ewes in this study preceded a significant decrease in circulating progesterone concentrations. RU 486 treatment greatly attenuated the antepartum relaxin surge, as seen in the control ewes; peak circulating concentrations of relaxin were lower but occurred earlier compared with the diluent-treated controls. The lower peak release of immunoreactive relaxin soon after RU 486 treatment of sheep may result from reduced relaxin synthesis and release at this time compared with greater relaxin synthesis and release seen a few days later in the diluent-treated animals. Regardless, immunoreactive relaxin concentrations are low at induced or normal parturition in sheep, as shown in this study, as well as in pigs. In spite of this, however, the RU 486-treated ewes lambed without complications of dystocia. There is a cotyledonary-caruncle type of placentation in this species, but there was no incidence of retained placenta during the postpartum period as a result of either RU 486 or relaxin treatment.

The circulating concentrations of RU 486 observed in this study were lower than those reported for pigs and cattle in which the drug was fed, or injected i.m. at lower doses, although the same pharmacokinetics was observed (Li et al., $1991 a, b, c)$. The differences among these species may result from an increased metabolism of RU 486 in sheep, or from an increased transplacental diffusion of the drug to the fetus. A rapid transplacental transfer of RU 486 has been reported in monkeys and humans (Wolf et al., 1988; Hill et al., 1990).

In summary, the results reveal that an antepartum relaxin surge occurs in sheep 4 days before normal parturition. RU 486 attenuates the relaxin surge, abruptly decreases circulating progesterone concentration, and advances an early, safe lambing. The results indicate that RU 486 precisely controlled the time of parturition in sheep in late pregnancy without detrimental effects of dystocia, retention of placenta, or delayed postpartum fertility.

We thank D. Philibert, Roussel-UCLAF (Paris, France), for RU 486 and anti-RU 486-3-carboxylmethyloxime-BSA antiserum; A. Jacot, Roussel-UCLAF (Paris, France), for $\left[{ }^{3} \mathrm{H}\right] \mathrm{RU}$ 486; B. G. Steinetz, New York University Medical Center (Tuxedo, NY), for antiporcine relaxin antibody and CM-B porcine relaxin; G. D. Niswender, Colorado State University (Fort Collins, CO), for progesterone antibody, GDN-337; P. G. Eness, Ambulatory Clinics, College of Veterinary Medicine, Iowa State University, for monitoring health status of experimental animals; C. R. Youngs and D. K. Hummel for animals used in the study; M. E. Shell, T. J. Randall, B. Bagna, C. J. Huang and K. E. Langner for excellent technical assistance, and P. Lahteenmaki, University of Helsinki, Finland, for advice on RU 486 extraction. O. S. Gazal was a Freedom from Hunger Scholar, Rotary International, the Rotary Foundation, Evanston, IL. This work was supported by USDA ARS CSRS OGPS Competitive Grant 88-CRCR-37242-3918 and lowa Biotechnology Council Grant AGD-86-2. Journal Paper J-14551 of the Iowa Agriculture and Home Economics Experiment Station, Ames, IA (Project Nos 2443, 2444, 2922, and 2273, the last a contributing project to North Central Regional Research Project NC-113).

\section{References}

Akinbami MA, Meredith S, Warren JE, Anthony RV and Day BN (1990) Cervical dilation, conception rate, and concentrations of progesterone and estradiol$17 \boldsymbol{\beta}$ in postpartum ewes treated with porcine relaxin Theriogenology 34 $927-940$

Anderson LL (1987) Regulation of relaxin secretion and its role in pregnancy Advances in Experimental Medicine and Biology 219 421-463 
Bagna B, Schwabe C and Anderson LL (1991) Effect of relaxin on facilitation of parturition in Holstein heifers joumal of Reproduction and Fertility 91 605-615

Baulieu EE (1989) Contragestion and other clinical applications of RU 486: an antiprogesterone at the receptor Science, NY 245 1351-1357

Benhamou B, Garcia T, Lerouge T, Vergezac A, Gofflo D, Bigogne C, Chambon P and Gronemeyer $\mathbf{H}$ (1992) A single amino acid that determines the sensitivity of progesterone receptors to RU 486 Science 225 206-209

Bischof P, Sizonenko MT and Herrmann WL (1986) Trophoblastic and decidual response to RU 486, effects on human chorionic gonadotrophin, human placental lactogen, prolactin and pregnancy-associated plasma protein-A production in vitro Oxford Human Reproduction I 3-6

Blair WH, Goodnight JH, Helwig JT and Council KA (1979) SAS User's Guide pp 121-130. SAS Institute, Cary, NC

Büllesbach EE and Schwabe C (1985) Naturally occurring porcine relaxins and large scale preparation of the B29 hormone Biochemistry 24 7717-7722

Das C and Catt KJ (1987) Antifertility actions of the progesterone antagonist RU 486 include direct inhibition of placental hormone secretion Lancet i 599-601

Felder KJ, Molina JR, Benoit AM and Anderson LL (1986) Precise timing for peak relaxin and decreased progesterone secretion after hysterectomy in the pig Endocrinology 119 1502-1509

Gaillard RC, Riondel A, Muller AF, Herrmann W and Baulieu EE (1984) RU 486: a steroid with antiglucocorticoid steroid activity that only disinhibits the human pituitary-adrenal system at a specific time of day Proceedings of the National Academy of Sciences, USA 81 3879-3882

Garfield RE, Gasc JM and Baulieu EE (1987) Effects of antiprogesterone RU 486 on preterm birth in the rat American Journal of Obstetrics and Gynecology 157 1281-1285

Garzo VG, Liu J, Ulmann A, Baulieu EE and Yen SSC (1988) Effects of an antiprogesterone (RU 486) on the hypothalamic-hypophyseal-ovarianendometrial axis during the luteal phase of the menstrual cycle Journal of Clinical Endocrinology and Metabolism 66 508-517

Haluska GJ, West NB, Novy MJ and Brenner RM (1990) Uterine estrogen receptors are increased by RU 486 in late pregnant rhesus macaques but not after spontaneous labor Journal of Clinical Endocrinology and Metabolism 70 18I-186

Healy DL, Chzousos GP, Schulte HM, Gold PW and Hodgen GD (1985) Increased adrenocorticotropin, cortisol and arginine vasopressin secretion in primates after the antiglucocorticosteroid RU 486: dose response relationships Joumal of Clinical Endocrinology and Metabolism 60 1-4

Heikinheimo O, Tevilin M. Shoupe D. Croxatto H and Lahteenmaki P (1986) Quantitation of RU 486 in human plasma by HPLC and RIA after column chromatography Contraception 34 613-624

Heikinheimo O, Ylikorkala O, Turpeinen U and Lahteenmaki P (1990) Pharmacokinetics of the antiprogesterone RU 486: no correlation to clinical performance Acta Endocrinologica 123 298-304

Herrmann WL, Schindler AM, Wyss $R$ and Bischof $P$ (1985) Effects of the antiprogesterone RU 486 in early pregnancy and during the menstrual cycle. In The Antiprogestin Steroid RU 486 and Human Fertility Control pp 179-198 Eds EE Baulieu and SJ Segal. Plenum Press, New York

Hill NCW, Selinger M, Ferguson J and MacKenzie IZ (1990) The placenta] transfer of mifepristone (RU 486) during the second trimester and its influence upon maternal and fetal steroid concentrations British Joumal of Obstetrics and Gynaecology 97 406-411

Kelly RW, Healy DL, Cameron MJ Cameron IT and Baird DT (1984) RU 486 stimulation of $\mathrm{PGF}_{2} \alpha$ production in isolated endometrial cells in shortterm culture. In The Antiprogestin Steroid RU 486 and Human Fertility Control pp 259-262 Eds EE Baulieu and SJ Segal. Plenum Press, New York

Kelly RW, Healy DL, Cameron MJ, Cameron IT and Baird DT (1986) The stimulation of prostaglandin production by two antiprogesterone steroids in human endometrial cells Journal of Clinical Endocrinology and Metabolism 62 1116-1123

Ledger WL, Webster MA, Anderson ABM and Turnbull AC (1985) Effect of prostaglandin synthesis on cervical softening and uterine activity during ovine parturition resulting from progesterone withdrawal induced by epostane Journal of Endocrinology 105 227-233

Li Y, Molina JR, Klindt J, Bolt DJ and Anderson LL (1989) Prolactin maintains relaxin and progesterone secretion by aging corpora lutea after hypophysial stalk transection or hypophysectomy in the pig Endocrinology 124 1294-1304

Li Y, Perezgrovas R, Gazal O, Schwabe C and Anderson LL (1991a) Antiprogesterone, RU 486, facilitates parturition in cattle Endocrinology 129 765-770

Li Y, Huang CJ, Klindt J and Anderson LL (1991b) Divergent effects of antiprogesterone, $\mathrm{RU} 486$, on progesterone, relaxin and prolactin secretion in pregnant and hysterectomized pigs Endocrinology $1292907-2914$
Li Y, Perezgrovas R, Gazal O, Huang C, Klindt J and Anderson LL (1991c) Kinetic changes in plasma concentrations of RU 486: comparisons among hysterectomized and pregnant pigs, and pregnant cattle and sheep. In Proceedings of the 73rd Annual Meeting of The Endocrine Society, 1991 Washington. $D C$, Abstract 1684

Li Y, Huang C, Klindt J and Anderson LL (1992) Stimulation of prolactin secretion in the pig: central effects of antiprogesterone, RU 486, and relaxin. In Proceedings of the 74th Annual Meeting of The Endocrine Society, San Antonio, TX, Abstract 775

Musah AI, Schwabe C, Willham RL and Anderson LL (1986) Relaxin on induction of parturition in beef heifers Endocrinology 118 1476-1482

Nemec LA, Loskutoff NM, Lasley BL, Fields MJ, Bowen MJ and Kramer DC (1988) The influence of relaxin and steroid pretreatment on cervical dilatation in ovariectomized ewes Theriogenology 29282 (Abstract)

Nieman LK, Choate TM, Chrousos GP, Healy DL, Morin M, Renquist D, Merriam GR, Spitz IM, Bardin CW, Baulieu EE and Loriaux DL (1987) The progesterone antagonist RU 486 New England Journal of Medicine 316 187-191

Niswender GD (1973) Influence of the site of conjugation on the specificity of antibodies to progesterone Steroids 22 413-424

O'Byrne EM and Steinetz BG (1976) Radioimmunoassay of relaxin in sera of various species using an antiserum to porcine relaxin Proceedings of the Society for Experimental Biology and Medicine 152 272-276

Ogle TF (1988) Kinetics of RU 486 interaction with progesterone for the progesterone receptor in rat placenta. In Proceedings of the 70 th Annual Meeting of The Endocrine Society, New Orleans, LA, Abstract 907

Porter DG, Lye SJ, Bradshaw JMC and Kendall JZ (1981) Relaxin inhibits myometrial activity in the ovariectomized non-pregnant ewe Joumal of Reproduction and Fertility 56 251-253

Puri CP, Katkam KR, D'Souza A, Elger WAG and Patil RK (1990) Effects of a progesterone antagonist, Lilopristone (ZK 98.734) on induction of menstruation, inhibition of nidation and termination of pregnancy in bonnet monkeys Biology of Reproduction 43 437-443

Raynaud JP, Azadian-Boulanger G and Bucourt R (1974) Anticorps specifiques de l'estradiol Joumal de Pharmacologie, Paris 5 27-32

Renegar RH and Larkin LH (1985) Relaxin concentrations in endometrial, placental, and ovarian tissue, and in sera from ewes during middle and late pregnancy Biology of Reproduction 32 840-847

Salmon J and Mouren M (1985) Radioimmunoassay of RU 486. In The Antiprogestin Steroid RU 486 and Human Fertility Control pp 99-101 Eds EE Baulieu and SJ Segal. Plenum Press, New York

Schwabe C (1983) Na-formyl-tyrosyl-relaxin: a reliable tracer for relaxin radioimmunoassay Endocrinology 113 814-815

Sherwood OD (1988) Relaxin. In The Physiology of Reproduction Vol II pp 585-673 Eds E Knobil and J Neill. Raven Press, New York

Sherwood OD, Crnekovic VE, Gordon WL and Rutherford JE (1980) Radioimmunoassay of relaxin throughout pregnancy and parturition in the rat Endocrinology 107 691-698

Shoupe D, Mishell DR, Lahteenmaki P, Heikinheimo O, Bigerson L, Madkour $H$ and Spitz IM (1987) Effects of the antiprogesterone RU 486 in normal women. I. Single-dose administration in the midluteal phase American Journal of Obstetrics and Gynecology 157 1415-1420

Snedecor GW and Cochran WG (1989) Statistical Methods (8th Edn). lowa State University Press, Ames

Stabenfeldt GH, Drost M and Franti CE (1972) Peripheral plasma progesterone levels in the ewe during pregnancy and parturition Endocrinology 90 144-150

Swahn ML, Bygdeman M, Cekan S, Xing S, Masironi B and Johannisson E (1990) The effect of RU 486 administered during the early luteal phase on the bleeding pattern, hormonal parameters and endometrium Oxford Human Reproduction 5 402-408

Taylor MJ (1987) Concentrations of progesterone and oestradiol-17 $\beta$ after administration of a $3 \beta$-hydroxysteroid dehydrogenase inhibitor to sheep in late pregnancy Joumal of Endocrinology 113 97-101

Vij U, Murugesan K, Kalita JC and Farooq A (1989) Interactions of antiprogestins with progesterone receptors in rat uterus Journal of Steroid Biochemistry 32 279-282

Wathes DC, Rees JM and Porter DG (1988) Identification of relaxin in the placenta of the ewe Journal of Reproduction and Fertility 84 247-257

Wolf JP, Chillik CF, Itskovitz J, Weyman D, Anderson TL, Ulmann A, Baulieu EE and Hodgen GD (1988) Transplacental passage of a progesterone antagonist in monkeys American Journal of Obstetrics and Gynecology 159 238-242 